\title{
The Experiences of Ethiopian Unaccompanied and Separated Migrant Children in Yemen
}

\begin{abstract}
International child migration has become a modern form of brutality. Ethiopia is also one of the source countries for thousands of young migrants leaving their villages in search of better opportunities elsewhere. The article aims to explore the experiences of Ethiopian unaccompanied and separated migrant children in Yemen. The study was conducted using constructivist research paradigm qualitative hermeneutic phenomenological inquiry with a cross sectional exploratory study design. Twelve purposefully selected returnees unaccompanied and separated migrant children from Yemen, with the registered age of sixteen and seventeen, had participated in the study. Data collected through in-depth interviews, focus group discussion and observation were analyzed thematically. The finding indicated dreadful experiences such as detention; bomb attack; physical abuses; emotional problems; imprisonment; starvation; military recruitment; and sexual abuse which were part of the lives of unaccompanied and separated migrant children in Yemen. The study concluded that the experiences of the migrant minors in Yemen were against the universally declared basic human and child rights that recognize the inherent dignity of all human beings and the developmental needs of children in particular. Findings implied points for comprehensive social work practice, and further research endeavors on the topic under investigation.
\end{abstract}

Keywords: Child migrants, Unaccompanied Child, Separated Child, Ethiopia, Experiences, Yemen

DOI: https://dx.doi.org/10.4314/ejossah.v14i1.1

* Corresponding Author, Lecturer, Department of Social Work, Gondar University, email:, bekelemolla2017@gmail.com,Tel: +251 918375 675, P.O. Box: 196/ Gondar

${ }^{\dagger}$ Assistant Professor, School of Social Work, Addis Ababa University, email: Zen_ed@yahoo.com, Tel: +251911882857, P.O. Box: 76/ Addis Ababa

This work is licensed to the publisher under the Creative Commons Attribution-NonCommercialNoDerivs License. 


\section{Introduction}

Unaccompanied and Separated Migrant Children (USMC) experienced extreme vulnerability to coercion, violence, and exploitation in the destination countries (Flamm, 2010). Minors also faced multiple problems, like inadequate understanding about the law of the 'new' land, language barriers, and being often situated in an undocumented status. United Nation Convention on the Rights of the Child /UNCRC (2005) reported that USMC in refugees may find themselves in very distressing situations in the destination country. The report indicated that they are exposed to discrimination, abuse, child labor and fail to access documentation that permits them to live legally. Moreover, it is difficult for undocumented children to access social services, public housing and schooling, despite international conventions that stress to guarantee these basic rights and services (Flamm, 2010).

Derluyn and Broekaert (2007) also revealed that USMC have faced very severe emotional and psychological problems such as anxiety, depression, and post-traumatic stress. These emotional and behavioral problems have resulted from the children's experiences in the country of origin and the whole process of the migration. Similarly, Unterhitzenberger, Eberle-Sejari, Rassenhofer, Sukale, Rosner and Goldbeck (2015) found out that unaccompanied minors have faced with the traumatic experiences and severe post-traumatic stress symptom (PTSS). Consistent with this point, Sanchez-Cao, Kramer and Hodes (2012) also insisted that USMC had high levels of psychological distress upon self-report, with at high risk for PTSS and depressive disorder though only few had access for mental health services.

Glind (2010) stipulated that when USMCs are detected by enforcement agencies, they are often sent to detention centers to await deportation. Thus, minors become more vulnerable and reduce their chances of securing decent work in the future. Conversely, independent child migration is not necessarily an exploitative or damaging experience for children, but rather a multidimensional phenomenon (IOM, 2011). For example, USMC displayed remarkable coping capacities such as a strong commitment to education and a capacity for hard work in the destination countries (Hopkins \& Hill, 2010).

Many young Ethiopian cross international borders in pursuit of a better life but they end up stranded in transit and destination countries (IOM, 2010). The number of Ethiopians arriving in Yemen is also greater than that of any other country from the Horn of Africa (RMMS, 2014). Although Yemen is in the most distracting situation for human life and work, RMMS (2017) revealed that from January to May, 55,000 people have left for Yemen from the Horn of Africa, 
where most were Ethiopians. In April 2017, for example, 5,750 migrants arrived in Yemen and the majority $(4,158)$ were from Ethiopia.

A survey by UNICF (2013) in Yemen indicated the availability of 271 Ethiopian USMC and the majority were 15-17 years old. One can estimate that this kind of figure can be found across the subsequent years. A preliminary assessment (in September 2016) also confirmed that UNICEF and IOM were working collaboratively to assist the return of Ethiopian USMC from Djibouti, Yemen, Saudi Arabia, Malawi, Tanzania and other African and Middle East countries. It was signposted that the majority of the returnees were from Yemen. This article is extracted from a larger research project on the migration experiences of Ethiopian USMC that was conducted in the year 2017. Leaving aside other experiences in the migration process, this article presents only the pre-returning experiences of the minors during their stay in Yemen.

\section{Statement of the Problem}

Studies conducted on the experiences of unaccompanied asylum seeking children so far are highly concentrated in the western context, specifically in the destination countries (Hopkins and Hill, 2008; Thomas, Thomas, Nafees and Bhugra, 2003; Spinhoven, Bean and Eurelings-Bontekoe, 2006; Laoire, White, Tyrrell and Carpenz-Mendez, 2012; Galloway, Smit and Kromhout, 2014; Unterhitzenberger et al., 2015). A number of studies such as those conducted by Abebaw (2012), Regt and Medareshaw (2015), Ababaw and Waganesh (2015), Yemisrach (2015), and Adamnesh and Adamek (2016) also investigated the experience of Ethiopian adult returnee migrants. The studies commonly reported that the migrants in the destination countries were devastated and had experienced various forms of problems.

The returnees faced various forms of abuses such as burdening with much household chores; working in the employers' relatives house forcefully; suffering from sleep deprivation and sleep disorder; deprivation of freedom of movement; absence of time for rest; denial of food/ deprivation of healthy food, physical safety and health care; and suffering from beating, emotional abuse, and sexual abuse/rape. Ababaw and Waganesh (2015) concluded that the various forms of abuse and exploitation led some of them to mental illness.

Child migration studies in Ethiopia have focused on internal migration characterized by rural-urban child outmigration. Most recent studies such as Frework (2007), Asefach (2012), Kelil (2015), Sintayehu (2016) and Megento and Wolde (2018) concentrated on child migration and trafficking to identify the attributable push and pull factors. Infrastructural limitations, demographic and 
socioeconomic variables i.e. low level of educational attainments, meager income, large family sizes, shortage of agricultural land, remarriage; and economic problems (poverty) in the place of origin were push factors. And the better opportunities at the destination areas were the major pulling factors for child migration and trafficking. However, the authors of this article could not come across studies conducted on Ethiopian independent international child migrants or USMC.

Thus, there is a clear knowledge gap regarding the experiences of Ethiopian USMC in the destination countries. To put landmark in the process of filling the gap, the article explores the pre-returning experiences of Ethiopian USMC from Yemen. The research questions include: what are the physical experiences that Ethiopian USMC encountered in Yemen; what are the emotional experiences that Ethiopian USMC encountered in Yemen; and what are the social experiences that Ethiopian USMC encountered in Yemen. The authors used these research questions as guiding framework for the study. Since the study, by design, was a phenomenological study aiming to document lived experiences of USMC, the authors did not need a different conceptual model apart from the research questions. Hence, this article aims to provide a holistic insight about the experiences of Ethiopian USMC in the destination country, Yemen, as reported by them. The authors discussed the findings in light of international legal instruments.

\section{Legal Instruments}

UNCRC (1989) is an international instrument that promotes the rights of children. The Convention depicts provisions that protect the rights of every child, regardless of nationality or immigration status. States have obligations to adopt the principles outlined in the Convention on the Rights of Children (CRC) to implement them in their jurisdictions. There are several provisions relevant to migrant children, including article 9 on separation of children from family or parents; article 10 on family reunification; article 19 on protection from all forms of violence; article 34 on protection from all forms of sexual exploitation and sexual abuse; article 35 on prevention from abduction; and article 37 on protection from torture or other cruel, inhuman treatment or punishment, and from unlawful and arbitrary deprivation of liberty. More strongly, Page 4 of article 11(1) stated that "States /Parties shall take measures to combat the illicit transfer and non-return of children abroad".

The other international legal instrument that pays a special attention for migrant children is International Migrants Bill of Rights/ IMBR (2011). Article 4 of the Bill identifies children as vulnerable group of migrants and highlights that actions and decisions concerning them need to be on their best interest and 
emphasizes that they are free to express their view in all matters affecting them. Specifically, USMC are entitled to international protection under international human rights law, international refugee law, international humanitarian law and various regional instruments (UNESCO, 2005; IOM, 2011). However, many of these are on paper than proper implementation in the specific contexts of states.

\section{Research Methods \\ Research Design}

This article aims to document the pre-returning experiences of Ethiopian USMC using their direct expressions, words, opinions, feelings and experiences. Hence, qualitative research methodology was an essential and a good fit to attain this. In particular, the study used the phenomenological approach to explore the lived experience of the Ethiopian USMC. According to Vanderstoep and Johnston (2009), phenomenology research focuses on how people experience a particular phenomenon through exploring how individuals construct their meanings about the experiences. Hermeneutic phenomenology is used for the study since it focuses on understanding the meaning of experience by searching for themes and engaging with the data interpretively (Sloan \& Bowe, 2014). The study targeted to come up with the multiple true meanings, values and definitions (Creswell, $2003 \&$ 2007) of participants about their pre-returning experiences in Yemen. The study was also exploratory in its nature which is applicable on issues that had been explored little (Kreuger \& Neuman, 2006). The issue of Ethiopian USMC, the pre-turning experience in particular, is scantly studied. The study used cross sectional research design to obtain an overall picture as it stands during the study (Kumar, 1996; Creswell, 2012).

\section{Selection of Study Participants}

The study participants had been selected from children who were temporarily residing in Addis Ababa Voluntary Assisted Returnee Transit Center at the time of the data collection. The center is a place where Ethiopian returnee USMC are temporarily settled and is located in Kirkos Sub City, Woreda 02/03 around Wongelawit Building. The setting was selected since it was the only place to find Ethiopian USMC altogether. Purposive sampling which is the best way of selecting the participants for hermeneutic phenomenological research was employed to select the participants (Kafle, 2011). The inclusion criteria were:(a) age (children whose registered age was at 16 and 17,years old); (b) educational level (who had reached grade four and above); (c) the number of days they can stay in the centre (who could spend at least five or more days at the center); (d) 
language (children who could speak the Amharic language were selected to avoid potential ethical dilemma of using third party as an interpreter); and (e) those who volunteered to participate.

Polkinghorne (as cited in Creswell, 2007) endorsed for phenomenological researchers to interview from 5-25 individuals who have all experienced the phenomenon. Likewise, in this study, six returnee USMC had participated for the in-depth interview. In addition, one FGD that consisted of six female members was conducted. As a result, the study had a total of (12) twelve participants. This final sample size was determined in the data collection process based on data saturation where further coding is no longer feasible.

\section{Methods of Data Collection}

The study relied on three data collection techniques: in-depth interview, FGD and observation. They are discussed below.

In depth interview: six USMC who all have returned from Yemen were involved. A minimum of three contacts were made with each of the participants, two for interviews and one for member checking. Wilcke (2002) proposed hermeneutic phenomenology interviews to last from one-and-a-half hours to three hours, depending on the amount of information the interviewee wished to share. However, the study had an interview schedule that lasted an hour to two hours by considering the nature and needs of the participants. The in-depth interviews were also guided by semi-structured interview that could give freedom to the researchers to shape and refine the questions asked (Corbetta, 2003).

Focus Group Discussion (FGD): Frietas, Oliveira, Jenkins and Popjoy (1998) acclaimed that to answer the question "how do people consider an experience, idea, or event?" utilizing FGD is feasible. FGD enabled us to recognize the shared group insight of minors on their pre-returning experiences in Yemen. The constructionist paradigm prompted to use pre-existing groups in the FGD for 'naturalistic' exchange of ideas, experiences and beliefs (Freeman, 2006; Onwuegbuzie et al., 2009). Thus, group of female USMC who originated from the same area and spent four months together in Yemen did participate. Two meetings were held with the discussants to generate rich data. The members of FGD participants were determined by Morgan's (2009) and Krueger's (2002) idea of the optimal number of the FGD participants to be between six and eight and the discussions were held for about two hours. Hence, six female FGD participants were involved. Since the number of male returnee USMC from Yemen were 
limited in the time of data collection, it was difficult to conduct FGD with male returnees.

Observation: notes were taken about the behaviours and activities of the participants during the in-depth interviews and FGD. The observation allowed collecting more consistent data via targeting the nonverbal clues and physical experiences of the participants. The recording notes were guided by observation checklist that emphasize on the verbal and facial expression of the participants in narrating their lived experiences.

\section{Methods of Data Analysis}

The data analysis was guided by Braun and Clarke's (2006) six phases of thematic analysis. Thus, the first step was familiarizing the researchers with the data. The verbal data were transcribed into written forms to make it more comfortable to conduct the thematic analysis. The double transcriptions i.e. transcribing the verbal data into written form with Amharic language and translating the Amharic written form to the English version were undertaken thoughtfully and carefully to make the researchers more familiar with the data. The nonverbal utterances were also targeted to retain the original nature of the data. Repetitive listening and reading of the raw data were carried out to get its actual meanings.

The second phase of the data analysis was generating initial codes. The codes were identified as a feature and referred to the most basic segment of the raw data that could be meaningful towards the study. The coded data were written on the text notes manually using highlighters and colored pens to indicate the potential pattern. At the third phase, searching for themes, the main activities were sorting out the different codes into potential themes to form the overarching themes. Then, main themes and sub themes were organized.

The fourth phase was reviewing the themes, which involved theme refinement based on the idea of internal homogeneity and external heterogeneity (as Patton cited in Braun \& Clarke, 2006). Thus, data within themes were cohered together profoundly; while there were clear distinctions between the themes. The candidate themes that were not really themes were also either collapsed or adjusted in another way, including breaking down large themes into smalls to produce meaningful and coherent report.

Defining and naming themes was the fifth step of the data analysis. At this point, the themes were defined and further refined to explore meaning to the data within each theme. In addition, within each theme, sub-themes were identified that are internally homogeneous. Finally, write-up of the report of the study was done 
in a way the readers can understand easily the complicated pre-returning experiences of Ethiopian USMC.

Data Quality Assurance and Trustworthiness: The collected data were transcribed within the same day of data collection and the interviewed participants were contacted for members'-checking before conducting another interview. This helped to identify and avoid the miss-interpretations and miss-presentations of the participants' idea in the early phase of the analysis. This involves seeking feedback from the participants about the findings to assess whether it reflects what they expressed to the researcher (Billups, 2014; Anney, 2014).

\section{Ethical Considerations}

Ethics involving children in general is complex (Bell, 2008) and unaccompanied minors in particular require ethically sensitive research strategies (Thomas \& Byford, 2003). The study adopted Hopkins's (2008) ethical considerations for USMC, which has three distinctive stages. First, a rapport was established with the service providers and social workers working in the Addis Ababa Voluntary Assisted Returnee Transit Center. Speaking to the adult services providers has assisted in getting well informed feedbacks about the behaviours and challenges of working with USMC. The social workers also served as gate keepers to get the right participants by exercising their duty of protecting vulnerable children.

Secondly, the rapport continued with the remaining service providers and the research participants. This enabled to develop trust with the participants in order to generate quality data. Finally, the participants were interviewed via accounting their experiences of being USMC. Thus, the questions were administered focusing on the present first (but it is not part of this article); immediate past second; and the earlier experiences at last (not part of this article) to reduce the possible emotional and behavioural problems of USMC because of their participation.

The participants were reminded about voluntary participation (informed consent), confidentiality and privacy issues. The unaccompanied or separated status of the participants made obtaining of parental consent impossible and hence consent from the social workers was must to have. It was more feasible as the social workers had a daily contact with the children for assessment and providing psycho-social supports in the center. The purpose of the study was fully explained; the motive of the research was clarified; and the participant children were offered time (10-15 minutes) to ask questions and think about participating in the study. Pseudonyms were used in the report to keep the study participants anonymous. 


\section{Findings}

This section outlines the data obtained from twelve USMC participants who returned from Yemen though their pre-planned country of destination was the Kingdom of Saudi Arabia (KSA). Among the participants, eight were females while the rest four were males. From these female participants six of them participated in the FGD. The other two female participants took part in the in-depth interviews. Similarly, all the male participants were involved in the in-depth interviews.

Table 1: the background description of the study participants

\begin{tabular}{|l|l|l|l|l|l|l|}
\hline No. & $\begin{array}{l}\text { Pseudo } \\
\text { Name }\end{array}$ & Sex & Age & Place of Origin & $\begin{array}{l}\text { Family } \\
\text { Involved in }\end{array}$ & $\begin{array}{l}\text { Duration in } \\
\text { Yemen }\end{array}$ \\
\hline \multicolumn{7}{|c|}{ In-depth Interview Participants } \\
\hline 1 & Jemberu & M & 17 & $\begin{array}{l}\text { Shewa Robit } \\
\text { North Shewa }\end{array}$ & Farming & $\begin{array}{l}\text { a month and } \\
15 \text { days }\end{array}$ \\
\hline 2 & Roth & F & 16 & $\begin{array}{l}\text { Shewa Robit } \\
\text { North Shewa }\end{array}$ & Trade & 3 months \\
\hline 3 & Musa & M & 17 & $\begin{array}{l}\text { Wollega, West } \\
\text { Oromia }\end{array}$ & Farming & 10 months \\
\hline 4 & Ali & M & 16 & $\begin{array}{l}\text { Were Babu, } \\
\text { Wollo }\end{array}$ & $\begin{array}{l}\text { Farming and } \\
\text { Weaving }\end{array}$ & $\begin{array}{l}1 \text { year and a } \\
\text { month }\end{array}$ \\
\hline 5 & Abeba & F & 16 & $\begin{array}{l}\text { Shewa Robit, } \\
\text { North Shewa }\end{array}$ & $\begin{array}{l}\text { Farming and } \\
\text { Petty trade }\end{array}$ & 3 months \\
\hline 6 & Jibril & M & 16 & $\begin{array}{l}\text { Gefira, North } \\
\text { Wollo }\end{array}$ & Farming & 9 months \\
\hline 7 & Fati & F & 17 & $\begin{array}{l}\text { Shewa Robit, } \\
\text { North Shewa }\end{array}$ & $\begin{array}{l}\text { Petty trade and } \\
\text { Weaving }\end{array}$ & 4 months \\
\hline 8 & Mesi & F & 17 & $\begin{array}{l}\text { Shewa Robit, } \\
\text { Farming and }\end{array}$ & 4 months \\
\hline
\end{tabular}


Bekele Molla and Zena Berhanu

\begin{tabular}{|l|l|l|l|l|l|l|}
\hline & & & & North Shewa & Petty trade & \\
\hline 9 & Zeyineb & F & 16 & $\begin{array}{l}\text { Shewa Robit, } \\
\text { North Shewa }\end{array}$ & Trade & 4 months \\
\hline 10 & Alem & F & 16 & $\begin{array}{l}\text { Shewa Robit, } \\
\text { North Shewa }\end{array}$ & $\begin{array}{l}\text { Petty trade } \\
\text { activities }\end{array}$ & 4 months \\
\hline 11 & Shashe & F & 17 & $\begin{array}{l}\text { Shewa Robit, } \\
\text { North Shewa }\end{array}$ & Farming & 4 months \\
\hline 12 & Tangut & F & 17 & $\begin{array}{l}\text { Shewa Robit, } \\
\text { North Shewa }\end{array}$ & Farming & 4 months \\
\hline
\end{tabular}

None of these participants had been involved in any regular activities in Yemen. Rather they returned voluntarily to their homeland by the efforts of the Ethiopian Government, IOM and UNICEF. During the time of data collection, they were temporarily settled in Addis Ababa Voluntary Assisted Returnee Transit Center and waiting for the reunification with their families. The article, as indicated earlier, presents one of the main themes of the bigger study i.e. the migration experiences of Ethiopian USMC in the destination country, Yemen, with its respective sub-themes that have been developed from the emerged codes.

\section{The Experiences of Ethiopian USMC in Yemen}

Participants of the study had a number of reasons to join the local traffickers/smugglers that have complex and well-organized but hidden networks with the international human traffickers /smugglers to arrive in Yemen. The KSA was their pre-planned destination. However, they were forced to terminate their voyage at Yemen and encountered with various forms of challenges and horrific experiences. Their devastating experiences started straight away from their arrival at the coast of Yemen and continued until they joined the program of UNICEF and IOM that was designed for returnees. At the Yemeni coast, the group of traffickers, who were waiting for the migrants, inflicted the first pungent traumatic experiences. The most commonly reported lived experiences are organized into six overarching themes and respective subthemes as physical challenges, emotional challenges, social experiences, health problems and services, loss of basic rights and sexual abuse. 


\section{Physical Challenges}

In Yemen, Ethiopian USMC experienced multiple physical problems that threatened their lives. The physical experiences were devastating, ranging from detention, imprisonment and military recruitment to bomb attack, physical abuse and starvation. The commonly reported physical challenges are narrated below.

Detention for Money: '...I was detained ... and ...paid...'

The first experience that participants came across in Yemen was detention for money by the human traffickers. Participants indicated human traffickers who detained them were known as Harami (an Arabic word to mean thieves, robbers...etc.). The aim of the detention was to robe and get the transferred money from the migrants' family. To attain this, the Harami took various detestable actions on the detainees. One of the participants, Musa, experienced detention for two days immediately following his arrival at the Yemeni shore. . He explained the situation as:

Immediate to our arrival at the Yemeni coast, a group of traffickers known as Harami came and took us to the place we did not know. They detained us in the ground level of a building and inspected us, even by taking off our cloths, to deprive us of such items as our pocket money, clothes, cell phones, identification cards or any other resources that they sought for. They also ordered us to provide [information about] family members that could pay ransom for our detention, including their name, cell phone and address.

It is also reported that the place where the minors had been detained was the roughest place that exposed the detainees to health problems. Jemberu described the place that he had been detained as: "frightening room that was untidy, smelly, dark and hot."

Participants informed their families about their detention and paid different amount of cash to be released. It was also stipulated that the amount of money that the Harami ordered the detainees to pay varied in terms of the country where the guarantor family members lived. Guarantor family members from Ethiopia were expected to pay about ETB 10,000 while from other countries such as from KSA it might mount to ETB 30, 000 to 40, 000. Musa stated it as: "As they forced us to give them our families address, I revealed the cell phone number of my brother, who lives in Saudi, and he paid about 5,500 Saudi Riyal, which is equivalent to ETB 30,000, within two days". 
Conversely, Jibril was released after seven months' detention when his father from Ethiopia paid ETB 10,000. He clarified his release as follows:

\begin{abstract}
I stayed seven months with the Harami and suffered from lots of problems such as hunger. I hadn't anyone to pay on time. I even requested my cousin, who lived in Saudi Arabia, though she refused. Finally, my father paid ETB 10,000, earned by selling his oxen.
\end{abstract}

The other participant, Ali, was also aware of the significant difference regarding the cash paid to Harami based on the country where the guarantor family members reside. He recognized the difference and arranged family members from Ethiopia, though the actual sources of the cash for his release were from his brother in KSA.

To fasten the ransom, the Haramis caused extreme brutalities and attacks on the minors as they were in detention.

Imprisonment: '...I had a year and one month ...imprisonment ...'

Participants reflected their imprisonment in Yemen regardless of their age. Some of them such as Abeba, Routh, Jemberu, and other female discussants were apprehended by the Yemeni government security forces and taken to Hudaida Central Prison of Yemen; while the others, such as Musa and Ali, were captured by the government opposition forces, Houthis, and forced to join $I b b$ prison. Abeba narrated processes of joining the Hudaida Central Prison of Yemen clearly and exclusively as: "After the exchange of massive volley of shots with the traffickers, the Yemeni government security forces apprehended and took us to the Hudaida Central Prison. We were imprisoned there for about four months".

Among others, Ali was also trapped at the Ibb Prison for six months. Then, he was forced to join Hudaida Central Prison in the process that he narrated as follows:

After we stayed for six months at Ibb Prison, they released us in a condition that the government forces could apprehend us. Then, government forces took us to the Hudaida Central Prison and we spent another seven months there. Totally, I had a year and onemonth imprisonment, six in the Ibb and seven in the Hudaida. 
Military Recruitment: '...Frequently entreated us to join their military...'

Musa revealed that he had frequent requests from the Yemeni government oppositions, Houthis, to join their military group. He further stated that the Houthis frequently entreated many Ethiopians for the military conscription. He described his experience of military recruitment as: "The Houthis group frequently entreated us (Ethiopian migrants) to join their military force though all of us rejected the request". He further mentioned that they were punished for longer imprisonment in the $I b b$ prison, which was administered by Houthis, and then transferred to the government prisons for their refusal. Musa thought that the refusal for military request resulted in five more-months imprisonment in the $I b b$ prison before the transfer to Hudaida Central Prison.

Bomb Attack: '...I lost my friends and lived with ... physical injures'

Participants such as Jibril and Jemberu suffered from the current civil war in Yemen (in 2017). These migrant minors were highly vulnerable to the air raids, bombs and violence. It was reported as one of the terrible and scary times participants had in Yemen. Jibril recounted his awful experience and main challenges in Yemen as:

While I was in the hand of Harami with other five Ethiopians, two females and three male migrants, 'Teyara' (an Arabic word to mean airplane) stroke the area. Unfortunately, all of them had died immediately after the strike. I was running to escape from that sacking life though I suffered with severe forms of physical injury such as knee and shoulder injuries. In the attack, I lost my friends and lived with severe forms of physical injuries.

Jibril, who had tumour on his knees and scar all around his body further recited the trophic miracle of escaping death in the incidence as follows:

I remember how we were before the attack. All of my friends were sitting while I was standing in front of them with some distance away. As soon as I heard the unusual sound from the sky, I realized that it was an explosive damaging substance thrown from Teyara. Fortunately, I reacted to it early and saved my life though I got wounded badly. Yet, others were incapable to respond and the substance sloughed off directly on them to take away their life immediately. 
Jemberu has also experienced bomb attack in Yemen. He recited how he escaped as:

The most unforgettable distressful experience I had in Yemen was bombing of the village that we (I and my friends) sheltered. The incidence killed several people, who were living in the village including Ethiopians that resided next to us. Though it was dream to escape death in that incidence, thanks to God, we all were saved.

Physical Abuse: 'Harami smashed and beat me...'

The data collected from Jibril, Ali, Abeba, Routh and female FGD discussants described the various forms of physical abuse they experienced in Yemen. The minors encountered the physical abuses in different setting including in the detentions and prisons. It was indicated that the Harami forced the migrants and their families to pay the release cash within the time frame by inflicting physical abuse on the detainees. The detainees who were able to pay the ransom within the time frame had got the possibility to avoid further physical abuses. Jibril, who spent seven months in detention, revealed various forms of physical injuries and attacks as:

Harami smashed and beat me for long until my family paid the ransom money. While they beat me, they forced me to shout more and louder to make my voice get out to my family through the phone. As punishment, they also decreed me to head down by holding my ears with my hands passing under my leg for a longtime, which caused hamstring and resulted in bleeding in my nose and mouth.

Contrarily, Ali, whose brother from KSA paid the release cash within three days, reflected his luck to avoid physical assaults and witnessed the torture of several Ethiopians as follows:

While I was detained in Yemen for three days, I witnessed the various forms of incarcerations and brutal punishments. First, Haramis turned two hands of the migrants to their back and tied it together to punish them easily. Then, they tethered a water container filled with 20 liters water container on the men's penis 
and ordered them to pull it over the floor. Others might also be ordered to be involved in sport activities that were impossible for the tired migrants and minors.

Beside the physical abuse wreaked from Harami, Abeba, Routh and female discussants encountered physical injuries and damages as a result of the gunfire exchanged between the human traffickers and the Yemeni government forces to take over the irregular migrants. During the exchange of the volley of shots, migrants faced various physical wounds in their attempt to save their lives. Abeba recited it as: "During the gunfire, the driver refused to stop the vehicle and we had an attempt to leap from the vehicle in order to save our life. At that movement, many of us faced injuries, hand and leg damages".

Routh also faced a similar volley of shots and her best friend leaped up from the vehicle to save her life. Routh further recounted her observation about her friend's physical injury as: "In the volley of shot, my best friend, whose age was 17 , jumped from the vehicle. She had badly fallen to the ground on her back and it looked that she was severely injured. Later, I was informed about her living with injuries".

Starvation: '...I faced ...hunger.'

In Yemen, participants also experienced bereft of access to basic human needs such as water and food. The starvation of those migrant children started immediately as they entered Yemen and continued in the prisons where they were imprisoned. Ali, Musa, Jenberu and Jibril are the participant minors who experienced starvation while they were with the Harami. Jibrill was the participant who stayed with the Harami for about seven months and narrated his experience as:

While I was detained by the Harami, I faced a severe form of hunger. Once per a day, mostly in the morning, I had untidy and unhygienic white boiled rice. Its amount was very limited; just it was about two mouthfuls at a time. It was also the experience that other migrants faced with if they had been apprehended by the Harami.

Moreover, it is signposted that Harami used starvations of detained migrants as a mechanism of speeding up the dispatch of the release money. Musa was 
deprived of food and drink until his family paid the ransom. Musa discussed the situation as:

I suffered from the absence of water and food for two days until my brother paid the required cash. I was so starved and I became unable to speak till I got water for drinking. Once my brother paid the money, I was allowed to get limited amount of water and food.

Participants also suffered with shortage of food and water in the prison where they had been arrested. Routh stated it as follows: "As the food was shoddy in quality and insufficient in amount; I felt bored to take it. I was also taking a meal with a group of 13 female prisoners". Likewise, the male participant, Musa, reported the food related challenge as: "The common food that we were taking was white boiled rice, which I disliked while I was here [Ethiopia] with my family. Its amount was also inadequate, just only for survival". Ali also explained more about the little amount of the food at Hudaida Central Prison as:

At Hudaida Central Prison, the meal was in groups that consisted of six to seven male prisoners. Members were fighting to get the minimum amount for survival from each meal. I can say it was just a mouthful of food an individual can take from a meal.

Participant who attempted to arrive at the KSA also encountered starvation during their voyage. Ali described the situation as: "After Harami released me, I traveled to cross Yemen in to KSA. In the process, I faced hunger for two days without accessing any food and water." Moreover, the study participants added that accessing quality water was too expensive and unaffordable for them. Jemberu described the quality of the water as:

In Yemen the water was very hot, salty and unsafe. It was too difficult for drinking. This led me to face lack of water and thirsty since a bottle of water was costly.

Emotional Challenges '...I feel bad and guilty.'

The participants also encountered emotional problems in Yemen that particularly resulted from the traumatic experiences. Participants reported their emotional challenges like frustration, nervousness, anxiety, distress and others. Routh, shared her emotional problem in Yemen as: "When my best friend got 
injured severely, I was on the vehicle and away from her without providing any assistance. When I remember about her, I feel guilty. I do not want even to talk about it" (turning her face to the left). In the movement she was talking about this experience, she looked nervous and her face changed easily.

The participants were also emotionally affected by the air raid incidence as it was part of their daily life. According to the female FGD participants, they were exasperated for their life in Yemen since they did not know what would happen next. Abeba also stipulated her frustration in Yemen as: "Life in Yemen was horrifying, for destructive artilleries from 'Teyara', which attacked the area we were living on daily basis. It caused the air to be poisoned desperately. That led me to cry for all over the days". Routh reported that observing the injured Ethiopian migrants by itself was a source of anxiety in Yemen. She signposted the Ethiopian migrants, who were attacked by Teyara, and put her feelings as:

While I was at Hudaida Central Prison of Yemen, I was shocked when I heard the attacks and deaths of many Ethiopians in Yemen. I also observed some of the victims of the attack that particularly joined the prison. That made me to be dismayed and worried about my future and I was crying daily.

\section{Social Experiences}

The social experiences of Ethiopian unaccompanied and separated migrant children can be considered into two divergent ways. On the one hand, participants had good relationship with their fellow migrants; on the other hand they have some tough social relationships with Yemenis. The social experiences of Ethiopian USMC are presented as follows.

Dispute with the Yemenis: ' ....we did not invite you for wedding...'

The data collected from the participants indicate their experience of facing hostility from and dispute with the Yemenis. Abeba and Ali, talked about their tussle with the prison officials and convicts in Yemen. The most commonly reported sources of quarrel were request for basic rights and services as well as for discharge from the prisons. Abeba stated her relationship with Hudaida Central Prison officials as:

Yemenis, specifically the officials of the prison, did not like me at all since I was the one who always asked them for various services and challenged them regarding our rights. We were also asking to be discharged and to return home as life in the prison became 
unmanageable. Yet, the Yemenis responded as 'we did not invite you here for wedding ceremony; you are the one who came. What we are doing for you is the goodwill of us'.

There were also conflicts and tensions between the Ethiopian migrants and Yemeni prisoners. Though all of the participants did not join the $I b b$ Prison, those who joined the prison have talked about the repugnant relation with the Yemenis. Ali recounted the tension and hostility in $I b b$ as:

We were involved in disputes with the personnel of the prison and Yemeni prisoners as we frequently requested for our discharge. We were involved with this notion since we were informed from the former Ethiopian migrant prisoners to protest frequently to get off from the prison within a short period of time. They used written message on the pieces of paper and on the wall of the prison to transfer their idea via the Ethiopian language, Amharic.

Strong Social Relationship with Migrants: '... migrants... were not heartless...'

It is reported that in Yemen, Ethiopian migrants had a positive relationship among themselves, including minors. This positive relationship had been used as a basic device to minimize or avoid challenges and traumatic experiences that the Ethiopian USMC had faced in Yemen. The participants pointed out that their relationship with the other migrants helped them to avoid the potential harrowing experience in their migration. Female participants of the study indicated that their relationship with the other migrants, particularly with the male, enabled them to avoid problems related to their femininity. They insisted that they did not encounter any form of sexual abuse because of their strong tie with the male migrants. Abeba narrated it exclusively as:

$I$ and other female migrants did not experience any problem related to our sex or gender in Yemen. The major reason was the strong social relationship we had with male migrants. In Yemen, until we were detached for imprisonment, we were cared for and protected by the male migrants.

Similarly, Jemberu avoided prolonged detention as well as the resultant physical and emotional challenges he might had faced because of his relationship with the other migrants. According to him, his friends' family covered the cash that 
set him free within two days from the Harami's detention. He stated the various forms of abuses he avoided as:

I avoided physical and other forms of abuse in the detention center since my friends' family covered the money that enabled me to be released within two days. As my friends asked their family to cover my cost too, they did it without any hesitation. Then, I got released from the center within two days like my friends.

In addition, the relationship among the migrants helped them to minimize the problem they encountered in Yemen. For instance, Jemberu reflected that migrants supported each other to alleviate the challenges they encountered. He thought that the starvation he experienced in Yemen was minimized by the provision he obtained from his friends. He narrated it as:

We (I and my friends) were sharing bottles of water in the group and taking it to save our lives. Specifically, I was the beneficiary in the process of sharing such resources since I did not have any money in that situation. The big asset I had in Yemen was my friends because they helped me in every circumstance that I had faced. Generally, friends and migrants, who originated from the same homeland, supported each other and were not heartless to one another.

Jibril also viewed his friend as an asset that helped him to handle the challenges he encountered in Yemen. He believed the various forms of support he obtained from his friends gave him emotional reliefs. He briefly elaborated it as:

The relationship that I had with my friends was the only asset I had there as they assisted me on daily basis. For instance, they assisted me to have a cell phone call to my family regularly every three days, which gave me a great emotional relief.

Health Problems and Services '...I became susceptible to health problems...'

In Yemen, participants had also faced various health problems. The most commonly reported health problems include bellyache, diarrhea, skin diseases, gastric and physical impairments. The most frequently recited causes were low quality of food and water, bomb attacks and strained foot journey. Abeba presented 
the health problems that she faced and its cause as: "Because of the poisoned food and water I took in Yemen, I frequently suffered with the various forms of health problems such as cholera, bellyache and gastric problems". Similarly, Musa believed that the water he used for hygiene purposes caused him skin problems. He described his health problems as:

After I used water from the Hudaida prison for personal sanitation, I became susceptible to health problems particularly skin diseases. Once I used the water, I started itching all around my body. Its effect is still visible and it bruised my skin, especially my face.

Jibril was the other participant who suffered from multiple health problems. According to him, he skipped death for more than twice in Yemen. He narrated his experience related to health as: "While I was detained by the Harami, I suffered from diarrhea. I underwent with it for more than four months. I was severely sick and nearly to die, which forced me to stop taking food for about fifteen days".

The other health problem that Jibril encountered was physical injury. Jibril encountered injuries and damages in different parts of his body. During the data collection, it was observable that his bloated right leg's knee hindered his mobility. The bruise and scar all over his body was detectable while he pulled out and took off his cloth. He described the wounds around his shoulder, throat, leg, eyelid and other parts of body as follows:

It is also painful around here (pointing to his right shoulder) as I was injured badly. I had a surgery around my (right) shoulder, which gave me some forms of relief. Look here, here and here! (Pointing to his throat, left leg and eyelid) there are also pebbles that were spilled during the attack in all of these parts of my body. You can look here and here again! (Curving up his cloth on his hands, legs as well as guts,) it is full of scar, which has resulted from the attack. It is also tickly and painful. The hair around my body was despaired though it started to recover. All these are aching, especially when the weather becomes cold; I feel I am being bitten on my right hand and leg.

The inaccessibility of the health services was the other challenge for the participant minors. For instance, Jibril stated that he underwent with his diarrhea for about four months without accessing any medical attention while he was living 
with the Harami; while at Hudaida Central Prison, they had access for health services though it was inadequate. Abeba stated the health services as: "There were few health services in response to our health problems though it was incomplete. There was no access for laboratories, rather, they ordered similar pills and tablets for different health problems that we encountered".

Loss of Basic Rights '... restricted movement ... inhumane treatments...'

The participants were forced to lose their natural and universally declared rights because of their migrant status, irrespective of their age and maturity. Some of the basic rights the migrant children lost included restriction of movement, lack of access to universal services and inhumane treatments. Ali explained the dreadful inhumane treatment in Yemen while he was with the Harami as: "The Harami did not consider us as human beings who have life and could suffer from the pains of the attacks and brutalities. They just ordered and forced both our families and us only to act according to their instruction".

Similarly, Abeba encountered inhumane treatments while she was in the Hudaida Central Prison of Yemen. She thought that Yemenis, particularly officials of the prison, were not considering the Ethiopian migrants as human beings entitled to the basic needs such as food and water. Abeba stated her experience: "While we were asking for additional food or change in the meal; they considered us as glutton (eater), not as human beings in need of basic needs such as food and water".

All of those participants who experienced the detention by Harami indicated that they were repudiated to move around there freely. Jemberu stated the situation as: "We (migrants) were denied to move beyond the detention room. Even we were hemmed in not to access rest-rooms as we needed". Routh and Musa stated that they were restricted not to visit Ethiopian victims of the civil war in Yemen though they were within the same prison.

Sexual Abuse '...it was all about using their femininity.'

The participants specified two divergent sets of ideas in relation to their gender differences. The first set of idea which was from the female participants Abeba, Routh and the other female FGD participants indicated that no one of them experienced sexual abuse in Yemen. Routh reflected her experience as: "I did not have any unique experience because of my sex or gender". Abeba also shared Routh's idea and elaborated the possible justifications as: 
I did not face any problem because of my femininity in Yemen. The reasons could be the strong relationship we had with the male migrants and our luckiness not to be detained by the Harami, who were potentially involved in sexual abusive acts. In Yemen, we also masked our face and looked like Yemenis to avoid potential offensive sexual acts.

On the contrary, Jibril stated the sexual exploitation and abuse of Ethiopian female USMC in Yemen by the Harami. He elaborated as:

I had seen that Ethiopian female migrants, including minors, were abused sexually by the Harami. The group were ordering and taking the female migrants away from the detention center for about many hours or few days. Some of these female migrants shared me what they did with them and it was all about using their femininity.

\section{Discussion}

The study participants experienced different multiple challenges in Yemen as discussed above. Similarly, UNCRC (2005), Flamm (2010), Glind (2010), IOM (2011) and Galloway, Smit and Kromhout (2014) indicated multidimensional experiences of undocumented USMC such as distressful experiences, detention and deportation, low access to the universal social services, and vulnerability and need for protection in the destination countries.

In Yemen, the participants experienced emotional problems like frustration, nervousness, anxiety, distress and others. Derluyn and Broekaert (2007), SanchezCao, Kramer and Hodes (2012) and Unterhitzenberger et al., (2015) reported similar emotional and behavioral problems that the USMCs faced in their destination countries. However, these previous studies allied the causes of the emotional and behavioral problem minors experience to their country of origin while the current article revealed that the emotional and behavioral problem resulted from the experiences in the destination country, Yemen. Contrarily, studies such as Ababaw and Waganesh (2015), Yemisrach (2015) and Adamnesh and Adamek (2016) specified unique experiences of Ethiopian adult migrants as abused by the employer; burdened with much household chores; forced to work in the employers' relatives house; suffered from sleep deprivation and sleep disorder, which were not the experiences of the study participants in Yemen. This might be 
also mainly because the child migrants were aiming to use Yemen as a transit country to Saudi Arabia where they aimed to get employed.

Despite sharing some common experiences with previous studies, the study uniquely identified the experiences of USMC in Yemen as detention for money; bomb attacks; military recruitments; conflicts and disputes with Yemenis as well as resultant physical and emotional problems. These experiences may have ensued from the participants' age and the recent conflict situation in Yemen. In general, the experiences of migrants in the destination countries were life threatening and devastating irrespective of their age and maturity. The experiences of Ethiopian migrant USMC in Yemen indicate the violation of universally declared human and child rights. These losses of basic rights also indicated the violation of the International Migrants Bill of Rights (2011) and basic human rights. Though the country (Yemen) ratified the UNCRC (1989), these experiences further displayed the lack of child right promotion and protection in line with the convention.

\section{Conclusion and Implications}

The study indicated that the experience of Ethiopian USMC in Yemen was devastating, horrific and life threatening that resulted in death, physical and emotional problems. The experiences were against the universally declared basic human rights that recognize the inherent dignity and equality and inalienable rights of all human beings irrespective of origin, status and age or maturity.

The pre-returning experiences of Ethiopian USMC from Yemen have several social work implications tailored to practice, policy, research and education. As USMC encountered distressing experiences, providing comprehensive social work services is deemed necessary. The professional social workers who are working with the returnees should take the lion's share to provide the services. Holistic practice that looks at the various dimensions of a person such as the physical, emotional, social and other challenges of USMC is also vital. The vulnerability of USMC entails to pay attention for their right to access basic health care and counselling services. Thus, with many other concerned professionals, the social workers must play their own professional roles of advocacy, community outreach and awareness creation based on the principles of social justice and equity.

Violation of the universally declared basic human and child rights was part of the experience for the Ethiopian USMC in Yemen. This provides insights on the poor implementation of the principles of the UNCRC and policies of the UNHCR in Yemen. Thus, the international humanitarian agencies such as UNICEF and IOM should evaluate their effort to promote universal human and child rights in the destination countries. Further studies on the following emerging issues are 
found to be important: the magnitude of Ethiopian independent international child migrants; the experience of USMC in other destination countries; perceptions and attitudes of USMC towards returning to home country; the challenges of returned Ethiopian USMC; processes and challenges of reintegrating USMC to their family and community; and the social work practices and roles at Addis Ababa Voluntary Assisted Returnee Transit Center. Filling these gaps will provide a proper lens to understand the problem broadly. The findings of this current article can be disseminated to provide insights about the Ethiopian USMC and their prereturning experiences as well as major challenges in the destination countries.

\section{Acknowledgement}

The participants of the study and the social workers who supported facilitating the data collection process are highly appreciated. We would like to acknowledge Addis Ababa University for covering partially the financial costs of the study. 


\section{References}

Abebaw, M. (2012). "Trafficked to the Gulf States: The experiences of Ethiopian returnee women." Journal of Community Practice, 20(1-2): 112-133.

DOI:10.1080/10705422.2012.649203

Abebaw, M., \& Waganesh Z. (2015). "Re-conceptualization human trafficking: The experience of Ethiopian returnee migrants." Journal of Trafficking, Organized Crime and Security, 1(1): 9-23.

Retrieved from: http://www.brownwalker.com/ojs/index.php/JTOCS

Adamnesh, A., \& Adamek, E. M. (2016). "The return migration experiences of Ethiopian women trafficked to Bahrain: '.. for richer or poorer, let me be on the hands of my people ..."'. African and Black Diaspora: An International Journal, 9(2): 243-256. DOI:10.1080/17528631.2015.1083176.

Anney, N. V. (2014). "Ensuring the quality of the findings of qualitative research: Looking at trustworthiness criteria." Journal of Emerging Trends in Educational Research and Policy Studies (JETERAPS), 5(2): 272-281.

Asefach, H. (2012). An Investigation into the experiences of female victims of trafficking in Ethiopia. (Unpublished Master's Thesis). University of South Africa, Cap Town.

Retrieved from:

http://uir.unisa.ac.za/bitstream/handle/10500/6043/thesis reda a.pdf;sequence=1

Atieno, P. O. (2009). "An analysis of the strengths and limitations of qualitative and quantitative research paradigms." Problems of education in the $21^{\text {st }}$ century, 13: 13-18. Retrieved from: http://oaji.net/articles/2014/457-1393665925.pdf

Baxter, P., \& Jack, S. (2008). "Qualitative case study methodology: Study design and implementation for novice researchers." The Qualitative Report, 13(4): 544-559.

Bell, N. (2008). "Ethics in child research: rights, reason and responsibilities." Children's Geographies, 6(1), 7-20. DOI:10.1080/14733280701791827.

Billups, F. (2014). The Quest for Rigor in Qualitative Studies: Strategies for Institutional Researchers. Providence: Johnson \& Wales University. Retrieved from:

https://www.airweb.org/eAIR/specialfeatures/Documents/ArticleFBillups.pdf

Braun, V., \& Clarke, V. (2006). "Using thematic analysis in psychology." Qualitative Research in Psychology, 3 (2): 77-101. ISSN1478-0887. Retrieved from: http://eprints.uwe.ac.uk/11735

Corbetta, P. (2003). Social Research: Theory, Methods and Techniques. London: Sage Publication. 
Bekele Molla and Zena Berhanu

Creswell, W. J. (2003). Research Design: Qualitative, Quantitative and Mixed Methods Approach ( $2^{\text {nd }}$ Ed.). USA: Sage Publication.

Creswell, W. J. (2007). Qualitative Inquiry and Research Design: Choosing among Five Approaches ( $2^{\text {nd }} E d$.). USA: Sage Publication.

Creswell, W. J. (2012). Educational research: Planning conducting and evaluating quantitative and qualitative research ( $4^{\text {th }} \mathrm{Ed}$.). Boston: Pearson.

Derluyn, I., \& Broekaert, E. (2007). "Different perspectives on emotional and behavioral problems in unaccompanied refugee children and adolescents." Ethnicity and Health, 12(2): 141-162. DOI: 10.1080/13557850601002296.

Flamm, S. (2010). "Linkage between migration and child labor: An International perspective." Stanford Journal of International Relations, 12(1): 15-25. Retrieved from http://web.stanford.edu/group/sjir/12-1/fall10-final_2.pdf

Freeman, T. (2006). "Methodological issues in nursing research: 'Best practice' in focus group research: making sense of different views." Journal of Advanced Nursing, 56(5): 491-49. DOI: 10.1111/j.1365-2648.

Freitas, H., Oliveira, M., Jenkins, M., \& Popjoy, O. (1998). The Focus Group, a qualitative research method (ISRC, Working Paper No. 010298). University of Baltimore: Merrick School of Business, Retrieved from: http://gianti.ea.ufrgs.br/files/artigos/1998/1998_079_ISRC.pdf

Frework, N. (2007). An exploratory study of child out-migration in Ethiopia: The Gurage Case. (Unpublished Master's Thesis). Addis Ababa University, Addis Ababa. Retrieved from: http://hdl.handle.net/123456789/8056

Galloway, M., Smit, M., \& Kromhout, M. (2014). "Between control and support: The protection of unaccompanied minor asylum seekers at risk: The Dutch case." International Migration, 53 (4): 51-61. DOI: 10.1111/imig.12178.

Georgetown University Law Center. (2011). "International Migrants Bill of Rights." Retrieved from:

https://scholarship.law.georgetown.edu/content.cgi article $=1006 \&$ context $=$ spp s_papers

Gill, P., Stewart, K., Treasure, E., \& Chadwick, B. (2008). "Methods of data collection in qualitative research: interviews and focus groups." Journal of British dental, 204 (6): 291-295. DOI: 10.1038/bdj.2008.192.

Glind, V. D. H. (2010). Migration and child labour: Exploring child migrant vulnerabilities and those of children left-behind [International Programme on the Elimination of Child Labour (IPEC) Working Paper, ISBN: 978-92-2124197-3 (Print); 978-92-2-124198-0 (Web PDF)], Geneva: International Labor Organization Retrieved from:

https://www.ilo.org/ipecinfo/product/download.do? 
Hopkins, P., \& Hill, M. (2010). "The needs and strengths of unaccompanied asylum-seeking children and young people in Scotland." Child and Family Social Work, 15: 399-408. DOI:10.1111/j.1365-2206.2010.00687.

Hopkins, P. (2008). "Ethical issues in research with unaccompanied asylumseeking children." Children's Geographies, 6(1), 37-48.

DOI:10.1080/14733280701791884.

International Organization for Migration (IOM). 2010. "The migrants". IOM Special Liaison Mission/Addis Ababa, 1(1): 1-4.

Retrieved from: https://www.iom.int/jahia/webdav/docs/ethiopia/Newsletter-SLM-Addis-TheMigrant1-Jan-Apr-2010.pdf

International Organization for Migration (IOM). (2011). Unaccompanied children on the move. Geneva: UNICEF: Unit for Children. Retrieved from: http://publications.iom.int/bookstore/free/UAM\%20Report_11812.pdf

Kafle, P. N. (2011). "Hermeneutic phenomenological research method simplified. Bodhi”: An Interdisciplinary Journal, 5: 181-200. Retrieved from: http://kucc.ku.edu.np/bodhi/vol5Narayan\%20Kafle.\%20Hermeneutic\%pdf

Kelil, D. (2015). The Impacts of child out-migration on the parents' and migrants' livelihood: The case of Muher and Aklil Woreda of Gurage Zone. (Unpublished Master's Thesis). Addis Ababa: Addis Ababa University. Retrieved from: http://etd.aau.edu.et.kelil\%20Demsis.pdf

Kreuger, L., \& Neuman, W. (2006). Social work research methods: quantitative and qualitative applications. Boston, New York: San Francisco.

Krueger, A. R. (2002). Designing and Conducting Focus Group Interviews. University of Minnesota: Retrieved from https://www.kth.se/social/upload/6566/Morgan.pdf

Kumar, R. (1996). Research Methodology: A Step by Step Guide for Beginners. London: Sage publication.

Laoire, N. C., White, A., Tyrrell, N., \& Carpena-éndez, F. (2012). "Children and young people on the move: geographies of child and youth migration." Geographical Association, 97(3): 129-134.

Laverty, M. S. (2003). "Hermeneutic phenomenology and phenomenology: A Comparison of historical and methodological considerations." International Journal of Qualitative Methods, 2 (3): 1-29.

Mathison, S. (1988). "Why triangulate?" Educational Researcher, 17(2): 13-17. Retrieved from: http://edr.sagepub.com/content/44/1.toc 
Bekele Molla and Zena Berhanu

Megento, T. \& Wolde, Y. (2018). "Child Trafficking as a Profitable Crime in Ethiopia". Sociology and Criminology-Open Access, 6(2). DOI: 10.4172/23754435.1000189

Morgan, D. (2009). Research Tools, Participants' Determination for Focus Group Discussion in Qualitative Research. Sage, UK.

Onwuegbuzie, J. A., Dickinson, B. W., Leech, L. N., \& Zoran, G. A. (2009). "A Qualitative framework for collecting and analyzing data in focus group research." International Journal of Qualitative Methods, 8(3): 1-21.

doi.org/10.1177/160940690900800301

Regional Mixed Migration Secretariat (RMMS). (2014). Blinded by Hope: Knowledge, attitudes and practices of Ethiopian migrants. Nairobi: The Regional Mixed Migration Secretariat. Retrieved from:

http://regionalmms.org/images/ResearchInitiatives/Blinded_by_Hope.pdf

Regional Mixed Migration Secretariat (RMMS). (2015). Regional Mixed Migration in the Horn of Africa and Yemen in 2015: End of year trend summary and analysis. Danish Refugee Council. Retrieved from: http://regionalmms.org/trends/AnnualReport2015.pdf

Regt, M, \& Medareshaw, T. (2016). "Deported before experiencing the good sides of migration: Ethiopian returning from Saudi Arabia." African and Black Diaspora: An International Journal, 9(2): 228-242.

DOI: 10.1080/17528631.2015.1083178.

Sanchez-Cao, E., Kramer, T., \& Hodes, M. (2012). "Psychological distress and mental health service contact of unaccompanied asylum-seeking children." Child: care, health and development, 39(5):651-9.

doi: 10.1111/j.1365-2214.2012.01406.x.

Sintayehu, M. (2016). Child rural-urban migration and migrant sending families perception towards child migration: The case of Haleha Kebele, Kucha Woreda, Gamogofa Zone, SNNPR. (Unpublished Master's thesis). Addis Ababa University: Addis Ababa.

Sloan, A., \& Bowe, B. (2014). "Phenomenology and hermeneutic phenomenology: the philosophy, the methodologies and using hermeneutic phenomenology to investigate lecturers' experiences of curriculum design." Quality \& Quantity, 48(3): 1291-1303. DOI:10.1007/s11135-013-9835-3

Spinhoven, P., Bean, T., \& Eurelings-Bontekoe, L. (2006). "Inconsistencies in the self-report of traumatic experiences by unaccompanied refugee minors." Journal of Traumatic Stress, 19 (5): 663-673. DOI: 10.1002/jts.20152

Thomas, S., \& Byford, S. (2003). "Research with unaccompanied children seeking asylum.” Journal of BMJ, 327(7428): 1400-1402. DOI: 10.1136/bmj.327.7428.1400 
Thomas, S., Thomas, S., Nafees, B., \& Bhugra, D. (2003) "II was running away from death' the pre-flight experiences of unaccompanied asylum seeking children in the UK." Child: care, health \& development, 30 (2): 113-122. DOI/10.1111/j.1365-2214.2003. 00404.x/full

United Nations (UN). (1989). "United nations convention on the rights of the child". Retrieved from: https://3531d710iigr2n4pro7k4po7k4kgvv-wpengine.netdna ssl.com/wp200910web.pdf

United Nations Children's Fund (UNICEF). (2013). Yemen Humanitarian Situation Report. UNICEF: Unit for children.

Retrieved from: https://www.unicef.org/appeals/files/UNICEF

United Nations Committee on the Rights of the Child (UNCRC). (2005). Treatment of unaccompanied and separated children outside their country of origin [General comments, No. 6 (2005), final unedited version]. Retrieved from: http://www2.ohchr.org/english/bodies/crc/docs/GC6.pdf

United Nations Education, Scientific and Cultural Organization (UNESCO). (2005). United Nations Convention on Migrants' Rights [International convention on the protection of the rights of all migrant workers and members of their families, information kit (SHS-2005/WS cld 25277)]. International migration Program

Available at: http://unesdoc.unesco.org/images/0014/001435/143557e.pdf

United Nations. (2011). International Migrants Bill of Rights: Commentary. Retrieved from: http://www.law.georgetown/centers-institutes/isim/imbr/upload/IMBRCommentariespdf

Unterhitzenberger, J., Eberle-Sejari, R., Rassenhofer, M., Sukale, T. Rosner, R., \& Goldbeck, L. (2015). "Trauma-focused cognitive behavioural therapy with unaccompanied refugee minors: a case series." BMC Psychiatry, DOI 10.1186/s12888-015-0645-0.

Vanderstoep, W. S., \& Johnston, D. D. (2009). Research methods for everyday life: Blending qualitative and quantitative approaches. San Francisco: John Wiley \& Sons, Inc.

Wilcke, M. M. (2002). "Hermeneutic phenomenology as a research method in social work." New Scholarship in the Human Services, 1(1): 1-10. Retrieved from: http://fsw.ucalgary.ca/currents_prod_v1/articles/wilcke_v1_n1.htm

Wojnar, M. D., \& Swanson, M. K. (2007). "Phenomenology: An Exploration." Journal of Holistic Nursing, 25(3): 172-180.

DOI: $10.1177 / 0898010106295172$ 
Bekele Molla and Zena Berhanu

Yazan, B. (2015). "Three approaches to case study methods in education: Yin, Merriam, and Stake." The qualitative Report, 20(2): 134-152. Retrieved from http://nsuworks.nova.edu/tqr/vol20/iss 2/12

Yemisrach, F. 2015. Experience of eight deported women Ethiopians who returned from Kingdom of Saudi Arabia. (Unpublished Master's thesis). Addis Ababa University, Addis Ababa.

Retrieved from http://hdl.handle.net/123456789/8056 